\title{
Impact of Microorganism Priming on Oxidative Processes and the Antioxidant Defense System of Grapes Infected with Downy Mildew
}

\author{
Evgeny O. Lutskiy, \\ Alisa E. Mishko and Maria A. Sundyreva* \\ North Caucasian Federal Scientific Center of Horticulture \\ Viticulture, Wine-making \\ Krasnodar, Russian Federation
}

Received 19.03.2021, received in revised form 20.05.2021, accepted 15.07.2021

\begin{abstract}
Priming plants with natural agents, including microorganisms, is a promising alternative to chemical methods of protection in growing plants and, particularly, in viticulture. However, the molecular mechanisms of the priming phenomenon are still not fully elucidated. The antioxidant system and reactive oxygen species are known to effectively modulate plant responses to various external influences. This study aimed to identify the relationship between the priming of grapes by microorganisms and the functioning of the antioxidant system in a protective response to downy mildew infection. The experiment was carried out on leaf discs of Muscat blanc susceptible to downy mildew infected with Plasmopara viticola and treated with microorganisms incompatible with the pathogen, as well as with the corresponding symbiotic microorganisms. During the compatible interaction between $P$. viticola and grapes, oxidative processes were suppressed with viniferin formation. Leaf treatments with Saccharomyces cerevisiae and Bacillus subtilis effectively curbed the development of downy mildew on grape leaves. Priming with these microorganisms did not lead to a significant change in the biochemical parameters of grapes. Nevertheless, subsequent downy mildew infection initiated the formation of viniferin and maintained $\mathrm{H}_{2} \mathrm{O}_{2}$ content at a high level. Thus, priming with microorganisms eliminates the physiological effects of compatible interactions between downy mildew and grapes associated with blocking oxidative processes. To suppress pathogen development, host defenses and antagonistic effects of microbial priming agents are required.
\end{abstract}

(C) Siberian Federal University. All rights reserved

This work is licensed under a Creative Commons Attribution-NonCommercial 4.0 International License (CC BY-NC 4.0).

* Corresponding author E-mail address: mari.sundy@bk.ru

ORCID: 0000-0003-0521-0827 (Lutskiy E.O.); 0000-0002-8425-5216 (Mishko A.E.); 0000-0002-1338-1725 (Sundyreva M.A.) 
Keywords: Plasmopara viticola, Saccharomyces cerevisiae, Bacillus subtilis, Venturia inaequalis, compatible interaction, antioxidant system.

Acknowledgements. The reported study was funded by RFBR according to the research project № 19-016-00210 A.

\title{
Окислительные процессы и антиоксидантные реакции
}

\section{у винограда при заражении милдью \\ на фоне прайминга микроорганизмами}

\author{
Е.О. Луцкий, А.Е. Мишко, М.А. Сундырева \\ Северо-Кавказский федеральный научный центр \\ садоводства, виноградарства, виноделия \\ Российская Федерация, Краснодар
}

\begin{abstract}
Аннотация. Прайминг растений естественными природными агентами, в том числе микроорганизмами, представляет интересную альтернативу химическим методам защиты в растениеводстве и в виноградарстве в частности. Однако молекулярные механизмы этого явления до конца не ясны. Известно, что антиоксидантная система растений и образование активных форм кислорода эффективно модулируют реакции растений на множество внешних воздействий, в том числе биотический стресс. В связи с этим цель исследования - выявление связи прайминга винограда микроорганизмами и функционирования элементов антиоксидантной системы в защитном ответе на заражение милдью. Эксперимент проводили на листовых дисках винограда восприимчивого к милдью сорта Мускат белый, зараженных Plasmopara viticola на фоне обработок несовместимыми и симбиотическими организмами. Определение содержания стильбенов, аскорбиновой кислоты проводили методом капиллярного электрофореза, содержание перекиси водорода, ТБК-активных веществ и активность ферментов - спектрофотометрически. Совместимое взаимодействие между P. viticola и виноградом характеризовалось подавлением окислительных процессов и образованием микроботоксичной окисленной формы ресвератрола - виниферина. Эффективными в сдерживании развития милдью были обработки листьев Saccharomyces cerevisiae и Bacillus subtilis. Прайминг данными микроорганизмами не приводил к существенному изменению биохимических показателей винограда, однако последующее заражение инициировало образование виниферина и сохранение содержания $\mathrm{H}_{2} \mathrm{O}_{2}$ на высоком уровне. Таким образом, прайминг микроорганизмами нивелирует физиологические эффекты совместимого взаимодействия милдью и винограда, связанные с блокированием окислительных процессов у винограда. Для полного сдерживания развития патогена требуются защитные реакции растения-хозяина и антагонистическое воздействие со стороны микроорганизмов - агентов прайминга.
\end{abstract}


Ключевые слова: Plasmopara viticola, Saccharomyces cerevisiae, Bacillus subtilis, Venturia inaequalis, совместимое взаимодействие, антиоксидантная система.

Благодарности. Исследование выполнено при финансовой поддержке РФФИ в рамках научного проекта № 19-016-00210 А.

Цитирование: Луцкий, Е.О. Окислительные процессы и антиоксидантные реакции у винограда при заражении милдью на фоне прайминга микроорганизмами / Е. О. Луцкий, А. Е. Мишко, М. А. Сундырева // Журн. Сиб. федер. ун-та. Биология, 2021. 14(3). С. 381-391. DOI: 10.17516/1997-1389-0357

\section{Introduction}

Most cultivated grape varieties are affected by fungal pathogens, which have harmful effects on all photosynthetic organs, disrupt nutritional processes - and in such a way disrupt the accumulation of plastic substances ensuring plant wintering - and damage both berries and the planting material harvested from the affected plants. This unavoidably reduces the crop yield, inflicting large economic losses and making the issue of devising novel methods to protect viticulture especially pressing. A correlation between the susceptibility of Vitis vinifera $\mathrm{L}$. to Plasmopara viticola and the lack of an effective pathogen recognition system in these species was proposed; namely, their defense system is not sufficiently efficient to fully activate and successfully curb the growth of pathogens (Di Gaspero et al., 2007). In addition, several studies have indicated some mechanism leading to the temporary activation of protective genes and proteins (Milli et al., 2012; Figueiredo et al., 2017). However, this system is neither fast nor sufficiently reliable to prevent the spread of the pathogen.

Viticulture largely depends on fungicides, the widespread use of which makes it possible to obtain high-quality grapes but at the same time leads to several problems: significant environmental load, decreased dietary properties of grapes, and considerable financial costs. Moreover, this may also be one of the reasons for pathogen resistance. As a viable alternative to chemical pesticides, immunity inducers may be used, including salicylic acid and its analogs (Dufour et al., 2013), jasmonic acid and methyl jasmonate (Belhadj et al., 2006), synthetic resistance inducers (Wang et al., 2019), and various ethylene producers (Chong et al., 2008). Although these methods are effective (Van Hulten et al., 2006), they are difficult to apply in the field, since the reactions caused by inducers of plant immunity are strictly determined by the time of their impact: the cycles of pathogen development and their spread in agrocenosis may start when the plastic and energy resources of the plant have already been exhausted. In this case, the simultaneous occurrence of many biotic and abiotic stresses tends to be the key problem. At present, the mechanism of setting plant defensive priorities remains understudied; therefore, the prediction of their metabolic properties is problematic, let alone generating a reliable defense response.

Under natural conditions, the immune response of plants is triggered either by substances secreted by the pathogen or the products of the plant's own cell destruction. Natural competitors of pathogens effectively reduce the spread of diseases in agricultural plants. Considering these two facts, the systems for biocontrol of pathogens exploiting antagonistic or sensitizing (incompatible) organisms are gaining an increasing renown. Antagonistic organisms make 
it possible to effectively control the number of pathogens, as they induce the death of the latter. The priming effect is achieved by harnessing socalled «sensitizing» organisms, which activate long-term systemic immune responses in plants. These responses do not require any serious energetic and plastic rearrangements of plant metabolism and are preferable in the long run. The interaction of a plant with nonspecialized pathogens can provoke an immune response, i. e., to sensitize a plant, although it hardly ever leads to disease (Yacoub et al., 2016; Mutawila et al., 2017; Baccari et al., 2019). Thus, by the time of a subsequent interaction with a specialized pathogen able to suppress the host's immune responses (Nascimento et al., 2019), the plant will have generated a pool of metabolites and protective substances to reduce the spread of a compatible pathogen.

Most environmental stresses, including biotic stresses, lead to the production of reactive oxygen species (ROS) in plants, which cause oxidative stress (Miller et al., 2007). At low concentrations, ROS play vital physiological roles in plants: maintaining a normal concentration of $\mathrm{H}_{2} \mathrm{O}_{2}$, which takes part in the biosynthesis of the cell wall and phytoalexins (Jabs et al., 1997), and providing protection against pathogens (Lamb, Dixon, 1997). At higher concentrations, ROS can damage membranes, proteins, chlorophyll, and nucleic acids (Scandalios, 1997), which may be dangerous for plants since biotic stresses are known to cause an increase in the production of reactive oxygen species (ROS) in plant cells (Tang et al., 2010). Hence, inducing the plant defense system against natural pathogens may be mediated by the antioxidant system involved in oxidative stress. This system relies on a class of antioxidant enzymes that maintain the levels of ROS produced in large amounts after the pathogen infects the plant in subtle equilibrium (De Gara et al., 2003). The aim of the present study was to investigate the relationship between the priming phenomenon in grapes and the functioning of the elements of the antioxidant system in a protective response to downy mildew infection.

\section{Materials and methods}

The experiment was carried out on leaf discs of Muscat blanc, the grape species susceptible to downy mildew. The leaves were collected from plants grown in growing chambers. The photoperiod was $16 / 8 \mathrm{~h}$. The experiment was carried out on leaf discs in Petri dishes with wet filter paper. The following treatments were exploited: Bacillus subtilis (Bs), Saccharomyces cerevisiae ( $\mathrm{Sc}$ ), Venturia inaequalis (Vi), and control - water. The Sc treatment was carried out by spraying the leaf discs with a suspension at a concentration of $10^{6}$ cells $\mathrm{mL}^{-1}$ from a pure culture of $S$. cerevisiae obtained from the leaves of the Merlot grape variety. To prepare the Vi inoculum, $2 \mathrm{~g} V$. inaequalis mycelium (provided by the Laboratory of biotechnological control of phytopathogens and phytophages of the North Caucasian Federal Scientific Center of Horticulture, Viticulture, Wine-making) was used per $20 \mathrm{~mL}$ distilled water. The final Vi suspension was sprayed onto the leaf discs. The Bs treatment was carried out using a commercial preparation of B. subtilis strain $26 \mathrm{D}$ (Fitosporin). Fitosporin powder $(0.2 \mathrm{~g})$ was diluted in $100 \mathrm{~mL}$ water, and after $2 \mathrm{~h}$, the grape leaf discs were sprayed according to the manufacturer's instructions. Twenty-four hours after treatment, a spore suspension of $P$. viticola $(\mathrm{Pv}) 3 \times 10^{6}$ spores $\mathrm{mL}^{-1}$ was applied by spraying. The spore suspension was prepared by washing off sporangia from the symptomatic leaves of greenhouse grape plants previously infected with downy mildew.

The effect of priming on physiological changes in grape leaves was assessed 48 and 96 hpi (hours post inoculation). The effect of downy mildew infection on biochemical 
changes in the grape leaves was determined 24 and $72 \mathrm{~h}$ after infection and appeared to be equal at 48 and 96 hpi. Downy mildew development was assessed by the proportion of leaf disc area yielding sporangiophores at $72 \mathrm{~h}$ after the infection.

To determine the total content of stilbenes, an extract was prepared by incubating $0.1 \mathrm{~g}$ of a sample triturated in liquid nitrogen overnight in the dark at $+4{ }^{\circ} \mathrm{C}$ in $2 \mathrm{~mL} 95 \%$ ethanol. The next day, the extract was centrifuged at $15000 \times \mathrm{g}$ for $15 \mathrm{~min}$; the supernatant was used for further analyses of the content of stilbenes. To determine the ascorbic acid level, an extract from leaves was prepared by incubating $0.1 \mathrm{~g}$ of the sample overnight at $+4{ }^{\circ} \mathrm{C}$ in $10 \%$ ethanol. Then, the stilbenes were determined by capillary electrophoresis on a Kapel 105 (Lumex, Russia); the focus of interest was resveratrol, viniferin, piceid and ascorbic acid in the cell extract. The enzymatic activity of superoxide dismutase (SOD), guaiacol peroxidase (POX) and lipid peroxidation (content of thiobarbituric acid reactive substances (TBARS)) were determined specrophotometrically using a Unico2800 UV/VIS spectrophotometer (USA) (Radyukina et al., 2012). The hydrogen peroxide content was determined by the FOX1 method (Wolff, 1994).

\section{Results}

B. subtilis is an antagonistic microorganism used in crop production to protect against various groups of pathogens. Sc (wine yeast) are natural symbionts of grapes that populate berries and vegetative organs. Vi was chosen as a priming agent as it is an incompatible fungal pathogen for grapes. The importance of microorganisms in controlling the development of downy mildew on the grape leaf discs varied. Vi failed to demonstrate effectiveness in reducing downy mildew development on grape leaves. Bs treatment reduced the leaf sporulation area by $23 \%$; Sc treatment showed the greatest efficacy (Fig. 1).

At $48 \mathrm{hpi}$, the content of hydrogen peroxide in grape leaves decreased after $\mathrm{Vi}$ and $\mathrm{Sc}$ treatments, as well as because of $\mathrm{Pv}$ infection. During this period, the $\mathrm{H}_{2} \mathrm{O}_{2}$ content did not change in the Bs treatment. $\mathrm{Pv}$ infection against a background of priming with microorganisms led to $\mathrm{H}_{2} \mathrm{O}_{2}$ content recovery to the control values at 48 hpi. At 96 hpi, $\mathrm{H}_{2} \mathrm{O}_{2}$ content in the $\mathrm{Pv}$ and $\mathrm{Sc}$

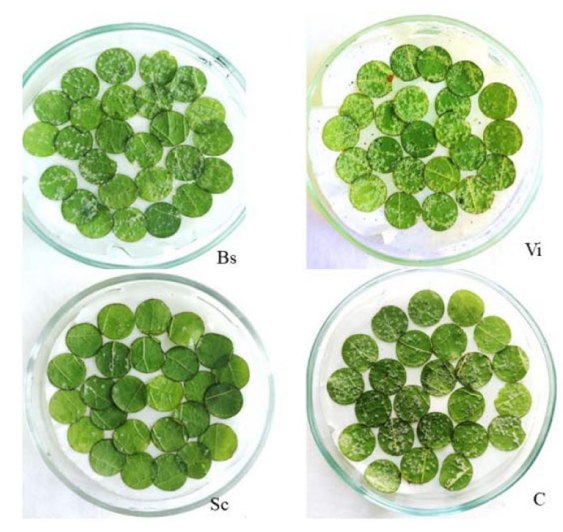

(a)

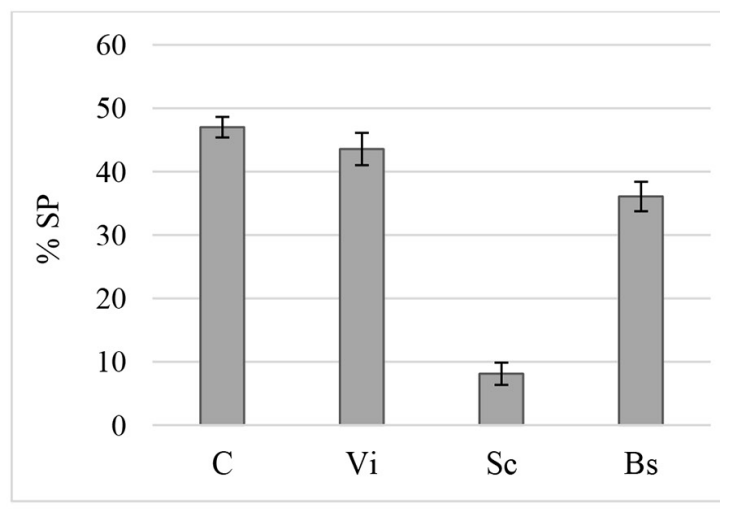

(b)

Fig. 1. Downy mildew development on grape leaf discs with experimental treatments (a). Leaf disc area yielding sporangiophores (b). The figures indicate the means with standard errors $(n=50)$. SP - percentage of the leaf disc area yielding sporangiophores, $\mathrm{C}$ - mock inoculated, Bs -Bacillus subtilis treatment, $\mathrm{Sc}-$ Saccharomyces cerevisiae treatment, and $\mathrm{Vi}-$ Venturia inaequalis treatment. 
treatments was below the control and similar to each other. The hydrogen peroxide content in the Bs treatment at $96 \mathrm{hpi}$ increased in comparison with that at 48 hpi. Downy mildew infection with microbial priming resulted in an increase in $\mathrm{H}_{2} \mathrm{O}_{2}$ content compared with the uninfected treatments. The content of hydrogen peroxide decreased in leaves with Bs $+\mathrm{Pv}$, similar to that at 48 hpi and 96 hpi (Fig. 2).

The content of TBARS during Sc treatment decreased compared with that of the control at 48 hpi. Bs increased the TBARS content, as did Vi $+\mathrm{Pv}$ infection. Interestingly, $\mathrm{Bs}+\mathrm{Pv}$ and $\mathrm{Sc}+$ $\mathrm{Pv}$ treatments reduced or did not change TBARS content compared with non-Pv-infected variants. At $96 \mathrm{hpi}, \mathrm{Pv}$ reduced the TBARS content in grape leaves, while $\mathrm{Vi}$ and $\mathrm{Bs}$ increased the TBARS content in the leaves. Interestingly, in $\mathrm{Vi}+\mathrm{Pv}, \mathrm{Bs}+\mathrm{Pv}$, and $\mathrm{Sc}+\mathrm{Pv}$ treatments, the TBARS content decreased compared with the uninfected Pv variants (Fig. 2).

$P$. viticola significantly reduced the activity of superoxide dismutase at $48 \mathrm{hpi}$. In contrast, $\mathrm{Vi}$, Sc, and Bs increased the enzyme activity. $P$. viticola infection against a background of microorganism treatments also had a stimulating effect on superoxide dismutase activity. At 96 hpi, the activity of superoxide dismutase in $\mathrm{Pv}$ increased significantly, while in other

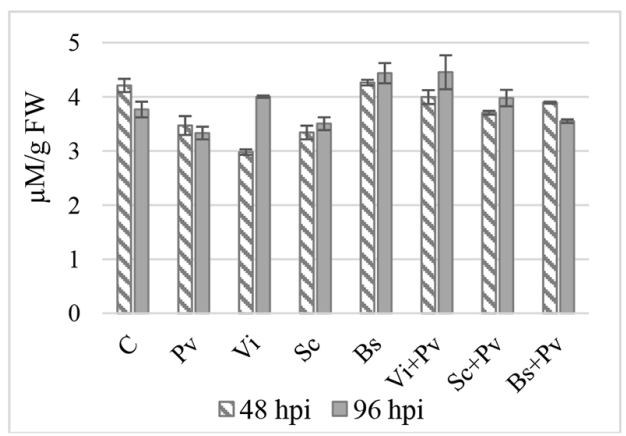

(a) treatments with microorganisms, it decreased and matched the control values. At the same time, $\mathrm{Pv}$ infection against a background of priming with microorganisms increased SOD activity. Interestingly, at 48 and 96 hpi in the $\mathrm{Sc}+\mathrm{Pv}$ treatment, SOD activation was less intense than in the other two variants of infection against a background of priming (Fig. 3a).

At 48 hpi, peroxidase activity increased intensively during $\mathrm{Pv}$ infection; however, treatment with $\mathrm{Vi}, \mathrm{Sc}, \mathrm{Bs}$, or combinations of $\mathrm{Pv}$ with other microorganisms did not significantly increase the activity of peroxidases. At $96 \mathrm{hpi}$, peroxidase activity under $\mathrm{Pv}$ infection was high, while Bs significantly increased POX activity (Fig. 3b). In Vi and Sc treatments, the POX activity increased compared with the control, whereas it was lower than that in $\mathrm{Pv}$ and Bs treatments at 48 hpi. The POX activity during Pv infection against a background of priming was lower than that in $\mathrm{Pv}_{\mathrm{v}}$ infection in mock-inoculated leaves at 96 hpi but increased compared with that at 48 hpi (Fig. 3b).

The content of ascorbic acid in grape leaves increased at 48 hpi under $\mathrm{Pv}$ infection, Sc treatment, and Bs inoculation (Fig. 4a). Pv infection against a background of priming with Bs and Sc led to a decrease in the content of ascorbate. At 48 hpi, the content of ascorbic acid

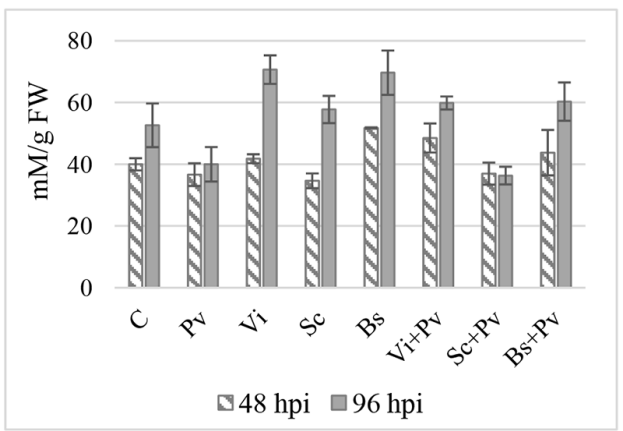

(b)

Fig. 2. The contents of hydrogen peroxide (a) and TBARS (b) in grape leaves. The figures represent the means with standard errors $(\mathrm{n}=3)$. FW - fresh weight. 


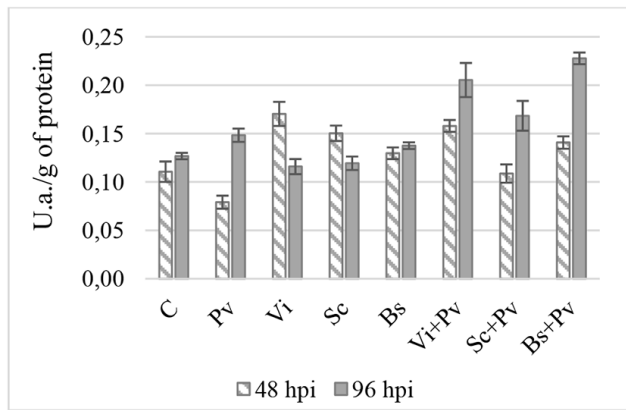

(a)

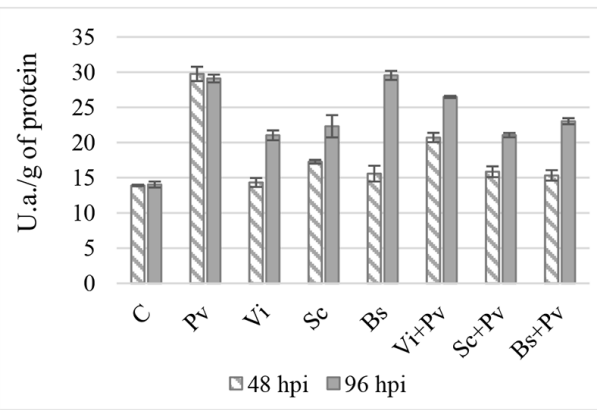

(b)

Fig. 3. The activity of antioxidant enzymes in grape leaves: (a) superoxide dismutase (SOD) and (b) guaiacol peroxidase (POX). The figures represent the means with standard errors $(n=3)$. U.a. - units of enzyme activity

in grape leaves in $\mathrm{Vi}$ and $\mathrm{Vi}+\mathrm{Pv}$ treatments was maintained at the control level or slightly higher. At 96 hpi, the same trend continued: the ascorbate content was high in $\mathrm{Pv}, \mathrm{Sc}$, and Bs treatments and decreased upon $\mathrm{Pv}$ infection against a background of priming. In $\mathrm{Vi}$ and $\mathrm{Vi}+\mathrm{Pv}$ treatments, as well as at $48 \mathrm{hpi}$, it was at the control level or slightly higher (Fig. 4a).

The content of resveratrol in grape leaves at 48 hpi was higher in all variants of the experiment than in the control (Fig. 4b). However, the resveratrol content appeared to be lower in the variant $\mathrm{Pv}, \mathrm{Vi}$, and $\mathrm{Sc}+\mathrm{Pv}$ treatments. At $96 \mathrm{hpi}$, a pronounced increase in the content of resveratrol in the Sc treatment and a decrease in combinations of $\mathrm{Pv}$ with priming microorganisms were observed (Fig. 4b).

Viniferin content increased significantly at 48 hpi in $\mathrm{Sc}, \mathrm{Bs}, \mathrm{Sc}+\mathrm{Pv}$ and $\mathrm{Bs}+\mathrm{Pv}$ treatments (Fig. 4c). In the Pv treatment, it was slightly higher than at the control level. In the Vi treatment, both without infection and with $\mathrm{Pv}$ infection, the viniferin content did not change compared with the control. At 96 hpi, a decrease in the content of viniferin in the experimental variants was marked. In the Pv treatment, as at $48 \mathrm{hpi}$, the content of viniferin in the leaves did not differ significantly from the control level. Pv infection against a background of Sc and Bs led to the restoration of the viniferin content to the control level (Fig. 4c).

At $48 \mathrm{hpi}$, the piceid content increased in $\mathrm{Pv}$, $\mathrm{Vi}$, and Bs treatments (Fig. 4d). In $\mathrm{Vi}+\mathrm{Pv}$ and $\mathrm{Bs}+\mathrm{Pv}$ treatments, the piceid content decreased slightly and remained at the control level. The content of piceid in the Sc treatment remained at the control level, and with an additional infection with Pv decreased below the control. At 96 hpi, the same tendency of changes in the content of piceid in grape leaves was noted as at 48 hpi. Generally, the highest piceid content was observed in the $\mathrm{Vi}$ and Bs treatments, and the lowest was observed in the Sc treatment (Fig. 4d).

\section{Discussion}

P. viticola, an obligate parasite of grapes, can suppress the defense reactions of the host plant by synthesizing molecules that disrupt the defense mechanisms of grapes. The susceptibility of $V$. vinifera to $P$. viticola tends to be caused by the lack of an effective pathogen recognition system that would allow full activation of the defense system to successfully curb the growth of pathogens. P. viticola reduced the content of hydrogen peroxide in grape leaves compared with the control samples at 48 hpi and 96 hpi. At 48 hpi, a decrease in SOD activity and a major increase in the activity of POX, as well as an increase in 


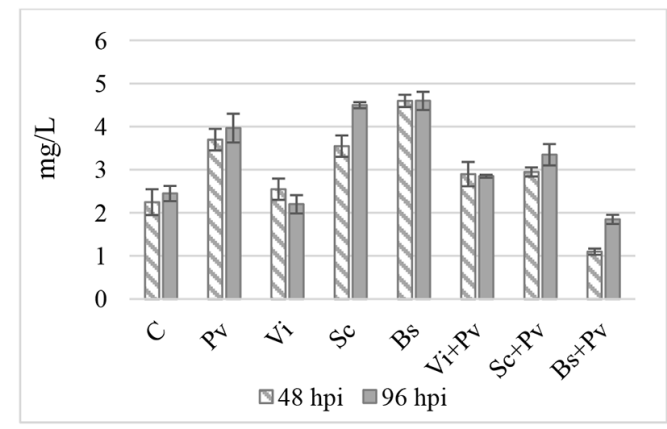

(a)

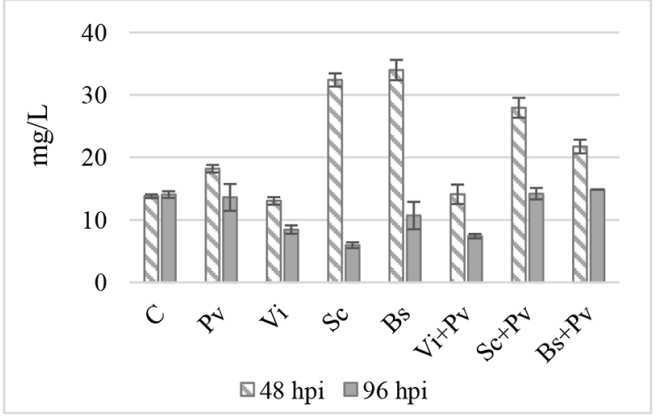

(c)

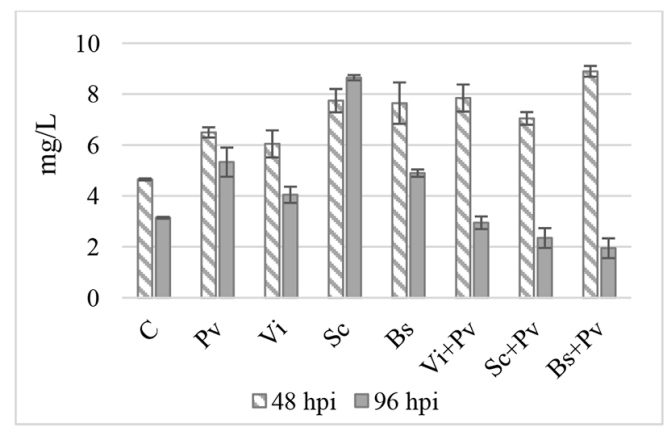

(b)

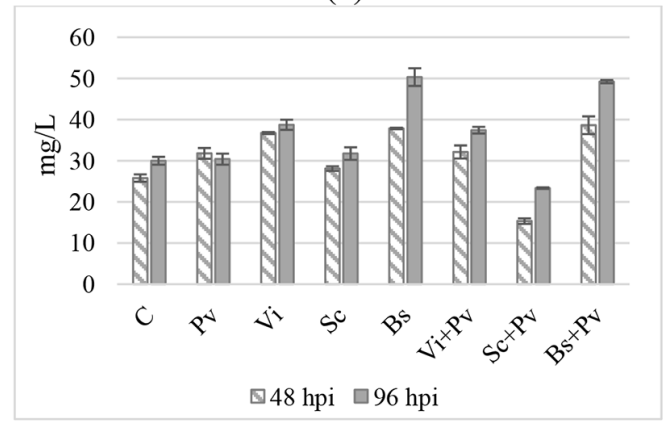

(d)

Fig. 4. The contents of ascorbic acid (a), resveratrol (b), viniferin (c) and piceid (d) in grape leaves. The data indicate the means \pm standard errors $(n=3)$

the content of ascorbate, were observed. These changes conditioned a decrease in the content of $\mathrm{H}_{2} \mathrm{O}_{2}$, while lipid peroxidation remained the same: such an environment is required for a compatible biotrophic pathogen to infect the plant (Polesani et al., 2008; Nascimento-Gavioli et al., 2017). Other peroxidases were also observed at elevated levels (up to a 20 -fold increase) in a compatible interaction between susceptible Pinot Noir and P. viticola (Milli et al., 2012), which may have been caused by a compatible interaction between $\mathrm{Pv}$ and $V$. vinifera. The cells of the host plant, influenced by a biotrophic pathogen, reduce the formation of ROS and, to a lesser extent, contribute to oxidative stress (Nascimento et al., 2019).

Stilbenes play a special role in protecting grapes from various diseases (Pezet et al., 2004), as they, especially resveratrol, generally exhibit high antioxidant activity (Biais et al., 2017).
Resveratrol is also glycosylated in the form of piceid, which is protected from enzymatic oxidation (Regev-Shoshani et al., 2003). Resveratrol and piceid have little or no toxic activity against $P$. viticola, while viniferin is highly toxic and can be considered an important marker of grape resistance to downy mildew (Pezet et al., 2004). Viniferins are products of the oxidation of resveratrol by peroxidases (Ros Barcelo et al., 2003). A slight increase in the content of viniferin, resveratrol, and piceid observed at 48 hpi indicates the activation of defensive processes, as well as an insufficient level of oxidative processes that typically activates the synthesis of toxic viniferin.

$V$. inaequalis treatment appeared to be ineffective in controlling $\mathrm{Pv}$. The production of $\mathrm{H}_{2} \mathrm{O}_{2}$ decreased relative to the control at 48 hpi. Infection with Pv against a background of $\mathrm{Vi}$ restored the content of hydrogen peroxide to 
the control level at $48 \mathrm{hpi}$, while it was above the control at 96 hpi. Thus, oxidative processes during $\mathrm{Pv}$ infection against a background of Vi seemed to be very pronounced, while SOD activity increased, and POX activity was lower than that by $\mathrm{Pv}$ infection alone. No changes in the contents of ascorbic acid and viniferin were observed, while resveratrol and piceid increased compared with the control. Supposedly, Vi is able to neutralize some effects resulting from the compatible interaction of grapes with $\mathrm{Pv}$. However, to curb the growth of $\mathrm{Pv}$, it is necessary to «correct the direction» of oxidative processes toward the conversion of phenolic compounds. In addition, a low accumulation of $\mathrm{H}_{2} \mathrm{O}_{2}$ with its compatible interaction with a biotrophic pathogen may be insufficiently toxic for the pathogen and, therefore, may be unable to inhibit the growth of the pathogen (Figueiredo et al., 2017; Nascimento et al., 2019).

The content of hydrogen peroxide, TBARS, and SOD activity increased in the Bs treatment at 48 hpi, which was more effective in controlling downy mildew development. Notably, the degradation of ascorbate occurred most intensively in the Bs treatment after $\mathrm{Pv}$ infection in the experimental variants. Infection of plants with pathogens leads to lipid peroxidation (Patel, Williamson, 2016), i. e., the cell membrane is disrupted, and cellular integrity is destroyed, which leads to further ROS formation. The lack of change in antioxidant capacity may be the cause of lipid peroxidation or oxidative processes in susceptible cultivars. At the same time, these processes could be considered an attempt of a susceptible cultivar to activate the first line of defense reactions using a burst of ROS (Mandal et al., 2011; Nascimento et al., 2019). Importantly, Bs significantly increased the formation of viniferin above the control values. Thus, with Bs priming, the effect of compatible interaction between grapes and $\mathrm{Pv}$ decreases, while the formation of a toxic oxidized form of resveratrol (viniferin) increases; however, the latter reaction does not suffice to suppress the development of Pv.

The most effective Sc treatment showed similar changes brought to $\mathrm{Pv}$ infection in lipid peroxidation rates. The SOD activity was higher than that of the control, and at $96 \mathrm{hpi}$, it increased significantly in the $\mathrm{Sc}+\mathrm{Pv}$ treatment, which led to an increase in the $\mathrm{H}_{2} \mathrm{O}_{2}$ content. The POX activity in infected and uninfected Sc leaves did not change. Ascorbate degradation in the $\mathrm{Sc}+\mathrm{Pv}$ treatment, in contrast to the $\mathrm{Bs}+\mathrm{Pv}$ treatment, was less intense. The decrease in piceid and resveratrol content and the corresponding significant increase in viniferin content during $\mathrm{Pv}$ infection against a background of Sc indicate «effective» oxidative processes inducing the formation of viniferin.

\section{Conclusion}

This study revealed that B. subtilis and $S$. cerevisieae priming, which reduced the development of $P$. viticola on grape leaves, ensures a higher level of $\mathrm{H}_{2} \mathrm{O}_{2}$ and maintains the associated SOD activity, as well as inhibiting the growth of peroxidase activity in the susceptible Muscat blanc grape variety, thus preventing a compatible interaction between $P$. viticola and $V$. vinifera. The experiment showed that lipid peroxidation did not have a significant effect on the control of downy mildew development. Therefore, a substrate for peroxidases can be assumed to play one of the key roles in the effective suppression of downy mildew development, since, with a decreased resveratrol concentration, a more pronounced formation of viniferin was observed with $S$. cerevisiae, while with less effective $B$. subtilis, intensive degradation of ascorbate occurred. Additional antagonistic action by priming agents might be needed to secure more effective containment of downy mildew development on susceptible grape varieties. 


\section{References}

Baccari C., Antonova E., Lindow S. (2019) Biological control of Pierce's disease of grape by an endophytic bacterium. Phytopathology, 109(2): 248-256

Belhadj A., Saigne C., Telef N., Cluzet S., Bouscaut J., Corio-Costet M.F., Mérillon J. M. (2006) Methyl jasmonate induces defense responses in grapevine and triggers protection against Erysiphe necator. Journal of Agricultural and Food Chemistry, 54(24): 9119-9125

Biais B., Krisa S., Cluzet S., Da Costa G., Waffo-Teguo P., Mérillon J. M., Richard T. (2017) Antioxidant and cytoprotective activities of grapevine stilbenes. Journal of Agricultural and Food Chemistry, 65(24): 4952-4960

Chong J., Le Henanff G., Bertsch C., Walter B. (2008) Identification, expression analysis and characterization of defense and signaling genes in Vitis vinifera. Plant Physiology and Biochemistry, 46(4): 469-481

De Gara L., De Pinto M. C., Tommasi F. (2003) The antioxidant systems vis-a-vis reactive oxygen species during plant-pathogen interaction. Plant Physiology and Biochemistry, 41(10): 863-870

Di Gaspero G., Cipriani G., Adam-Blondon A.-F., Testolin R. (2007) Linkage maps of grapevine displaying the chromosomal locations of 420 microsatellite markers and 82 markers for R-gene candidates. Theoretical and Applied Genetics, 114(7): 1249-1263

Dufour M.C., Lambert C., Bouscaut J., Mérillon J. M., Corio-Costet M.F. (2013) Benzothiadiazoleprimed defence responses and enhanced differential expression of defence genes in Vitis vinifera infected with biotrophic pathogens Erysiphe necator and Plasmopara viticola. Plant Pathology, 62(2): 370-382

Figueiredo A., Martins J., Sebastiana M., Guerreiro A., Silva A., Matos A.R., Monteiro F., Pais M.S., Roepstorff P., Coelho A.V. (2017) Specific adjustments in grapevine leaf proteome discriminating resistant and susceptible grapevine genotypes to Plasmopara viticola. Journal of Proteomics, 152: 48-57

Jabs T., Tschope M., Colling C., Hahlbrock K., Scheel D. (1997) Elicitor-stimulated ion fluxes and $\mathrm{O}_{2}^{-}$from the oxidative burst are essential components in triggering defense gene activation and phytoalexin synthesis in parsley. Proceedings of the National Academy of Sciences of the United States of America, 94(9): 4800-4805

Lamb C., Dixon R.A. (1997) The oxidative burst in plant disease resistance. Annual Review of Plant Physiology and Plant Molecular Biology, 48: 251-275

Mandal S., Das R. K., Mishra S. (2011) Differential occurrence of oxidative burst and antioxidative mechanism in compatible and incompatible interactions of Solanum lycopersicum and Ralstonia solanacearum. Plant Physiology and Biochemistry, 49(2): 117-123

Miller G., Suzuki N., Rizhsky L., Hegie A., Koussevitzky S., Mittler R. (2007) Double mutants deficient in cytosolic and thylakoid ascorbate peroxidase reveal a complex mode of interaction between reactive oxygen species, plant development, and response to abiotic stresses. Plant Physiology, 144(4): 1777-1785

Milli A., Cecconi D., Bortesi L., Persi A., Rinalducci S., Zamboni A., Zoccatelli G., Lovato A., Zolla L., Polverari A. (2012) Proteomic analysis of the compatible interaction between Vitis vinifera and Plasmopara viticola. Journal of Proteomics, 75(4): 1284-1302

Mutawila C., Stander C., Halleen F., Vivier M. A., Mostert L. (2017) Response of Vitis vinifera cell cultures to Eutypa lata and Trichoderma atroviride culture filtrates: expression of defence-related genes and phenotypes. Protoplasma, 254(2): 863-879 
Nascimento R., Maia M., Ferreira A.E.N., Silva A.B., Freire A.P., Cordeiro C., Silva M.S., Figueiredo A. (2019) Early stage metabolic events associated with the establishment of Vitis viniferaPlasmopara viticola compatible interaction. Plant Physiology and Biochemistry, 137: 1-13

Nascimento-Gavioli M.C.A., Agapito-Tenfen S.Z., Nodari R. O., Welter L.J., Mora F.D.S., Saifert L., da Silva A. L., Guerra M.P. (2017) Proteome of Plasmopara viticola-infected Vitis vinifera provides insights into grapevine Rpv1/Rpv3 pyramided resistance to downy mildew. Journal of Proteomics, 151: 264-274

Patel T.K., Williamson J.D. (2016) Mannitol in plants, fungi, and plant-fungal interactions. Trends in Plant Science, 21(6): 486-497

Pezet R., Gindro K., Viret O., Spring J.-L. (2004) Glycosylation and oxidative dimerization of resveratrol are respectively associated to sensitivity and resistance of grapevine cultivars to downy mildew. Physiological and Molecular Plant Pathology, 65(6): 297-303

Polesani M., Desario F., Ferrarini A., Zamboni A., Pezzotti M., Kortekamp A., Polverari A. (2008) cDNA-AFLP analysis of plant and pathogen genes expressed in grapevine infected with Plasmopara viticola. BMC Genomics, 9: 142

Radyukina N.L., Ivanov Yu.V., Shevyakov N.I. (2012) Methods for assessing the content of reactive oxygen species, low molecular weight antioxidants and the activities of the main antioxidant enzymes. Molecular-genetic and biochemical methods in modern plant biology. Kuznetsov V.V., Kuznetsova V.V., Romanova G.A. (eds.) Moscow, BINOM. Laboratoriya znaniy, p. 355-356 (in Russian)

Regev-Shoshani G., Shoseyov O., Bilkis I., Kerem Z. (2003) Glycosylation of resveratrol protects it from enzymic oxidation. Biochemical Journal, 374: 157-163

Ros Barcelo A., Pomar F., Lopez-Serrano M., Pedreno M. A. (2003) Peroxidase: a multifunctional enzyme in grapevine. Functional Plant Biology, 30(6): 577-591

Scandalios J. G. (1997) Introduction. Free Radical Biology and Medicine, 23(3): 471-472

Tang K., Zhan J.-C., Yang H.-R., Huang W.-D. (2010) Changes of resveratrol and antioxidant enzymes during UV-induced plant defense response in peanut seedling. Journal of Plant Physiology, 167(2): 95-102

Van Hulten M., Pelser M., Van Loon L.C., Pieterse C.M.J., Ton J. (2006) Costs and benefits of priming for defense in Arabidopsis. Proceedings of the National Academy of Sciences of the United States of America, 103(14): 5602-5607

Wang K. T., Wu D.Z., Guo D. Q., Du M. Y. (2019) $\beta$-aminobutyric acid induces disease resistance against Botrytis cinerea in grape berries by a cellular priming mechanism. Acta Alimentaria, 48(2): $177-186$

Wolff S.P. (1994) Ferrous ion oxidation in presence of ferric ion indicator xylenol orange for measurement of hydroperoxides. Methods in Enzymology, 233: 182-189

Yacoub A., Gerbore J., Magnin N., Chambon P., Dufour M. C., Corio-Costet M.F., Guyoneaud R., Rey P. (2016) Ability of Pythium oligandrum strains to protect Vitis vinifera L., by inducing plant resistance against Phaeomoniella chlamydospora, a pathogen involved in Esca, a grapevine trunk disease. Biological Control, 92: 7-16 